\title{
Evaluation of Roof Bolting Requirements Based on In-Mine Roof Bolter Drilling
}

(Contract No. DE-FC26-01NT41056)

Project Duration: Dec. 18, 2000 - Dec. 17, 2003

\section{Quarterly Technical Progress Report}

\author{
Report Period
}

December 18, 2000 - March 31, 2001

Syd S. Peng (Principal Investigator)

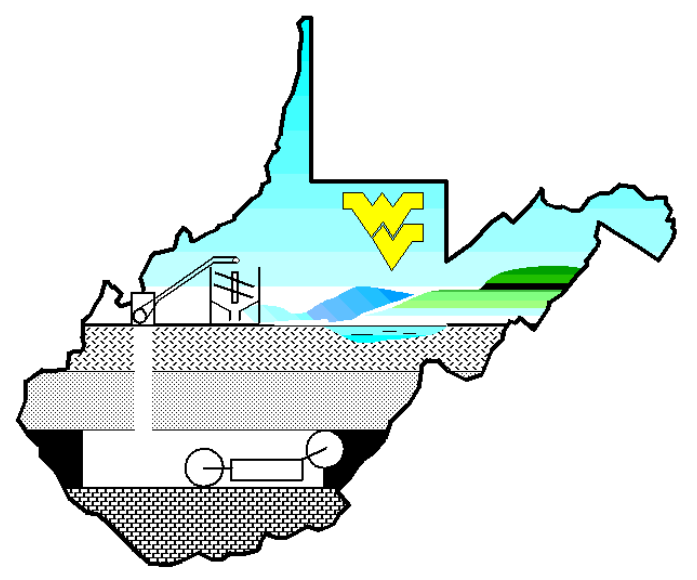

Department of Mining Engineering

West Virginia University

Morgantown, WV 26506-6070

Tel: 304-293-7680 ext. 3301

E-mail:sspeng@mail.wvu.edu

April 15, 2001 


\title{
DISCLAIMER
}

This report was prepared as an account of work sponsored by an agency of the United States Government. Neither the United States Government nor any agency thereof, nor any of their employees, makes any warranty, express or implied, or assumes any legal liability or responsibility for the accuracy, completeness, or usefulness of any information, apparatus, product, or process disclosed, or represents that its use would not infringe privately owned rights. Reference herein to any specific commercial product, process, or service by trade name, trademark, manufacturer, or otherwise does not necessarily constitute or imply its endorsement, recommendation, or favoring by the United States Government or any agency thereof. The views and opinions of authors expressed herein do not necessarily state or reflect those of the United States Government or any agency thereof.

\begin{abstract}
In this quarter, the research effort is to develop the drill control unit (DCU) that acquire, store drilling parameters and control the drilling operation. The relevant publications have been reviewed and the methodology developed by previous researchers has been evaluated using the collected data in our laboratory and field tests conducted prior to the start of this project. Numerical modeling for exploring roof bolting mechanism has been started.
\end{abstract}




\title{
TABLE OF CONTENTS
}

\section{Disclaimer}

\author{
Abstract \\ Research Objectives \\ Experimental \\ Results and Discussion \\ Conclusions \\ Reference
}




\section{$\underline{\text { Research Objectives }}$}

Roof bolting is the most popular method for underground openings in the mining industry, especially in the bedded deposits such as coal, potash, salt etc. In fact, all U.S. underground coal mine entries are roof-bolted as required by law.

However, roof falls still occur frequently in the roof bolted entries. The two possible reasons are: the lack of knowledge of and technology to detect the roof geological conditions in advance of mining, and lack of roof bolting design criteria for modern roof bolting systems.

This research is to develop a method for predicting the roof geology and stability condition in real time during roof bolting operation. Based on such information, roof bolting design criteria for modern roof bolting systems will be developed for implementation in real time.

For the prediction of roof geology and stability condition in real time, a microprocessor will be used and a program (ROOFSTAB) developed to monitor the drilling parameters. These parameters include thrust, penetration rate, rotation torque, rotation rate, drill position, and vacuum condition. At the same time, rock cores will be obtained a borehole drilled immediate next to bolt hole for the determination of the mechanical properties and structure of the rock strata within the bolting horizon. A relationship or relationships will be established between these drilling parameters and the mechanical and structural data of the roof strata. A roof bolter control system will be developed to monitor these drill parameters. For the development of ROOFSTAB drilling parameters will be obtained from four different coal seams in four mine sites. With this information, a computer program will be developed for use in conjunction with the roof bolter for realtime prediction of strata mechanical properties and structures in roof strata within the bolting horizon.

For the development of roof bolting design criteria, numerical simulations will be performed to investigate the mechanisms of modern roof bolting systems including both the tension and non-tensioned (or fully grouted) bolts. Parameters to be studied are: bolt size/strength, bolt length, bolt spacing, grout annulus and length, and roof geology (massive strata, fractured, and laminated or thinly-bedded). The results of these experiments will be analyzed to develop a roof bolting criterion or criteria program (ROOFBOLT) that will be combined with the ROOFSTAB for use in conjunction with roof bolt installation.

The following main tasks are to be performed for achieving the proposed research objectives:

A. Development of Operator Control Technology for Monitoring Roof Bolter Drill Operations Parameters.

B. Laboratory and Underground Testing.

C. Drill Parameters Data Analysis and Correlation with Roof Stability Conditions Software Development for Mapping of Roof Geological Conditions

D. Laboratory Tests to Investigate the Mechanisms of Roof Bolting Using Simulated Materials

E. Development of Roof Bolting Design Criteria for Implementation in Primary Roof Bolting Cycle 


\section{EXPERIMENTAL}

In 2000 prior to the award of this project, the development of the feedback control system (Fig. 1) was completed. A series of laboratory and a couple of underground tests were performed. The data were analyzed and preliminary results were summarized in a paper presented at the 2001 SME Annual Meeting in Denver, CO, February 26 - 28, 2001.

\section{RESULTS AND DISCUSSION}

West Virginia University has been cooperating with J.H. Fletcher \& Company in the development and application of the roof bolter feedback control system (Drilling Control Unit or DCU as shown in Fig. 1) since June 1999 including submission of the research proposal resulting in the award of this contract research project.

Analysis of the preliminary results showed that improvements in the feedback control system and methods of data analysis are needed in order to achieve the project objectives. Therefore, these tests were exploratory, the results of which are served as a basis for improving the task plans for initiating this project during this reporting period.

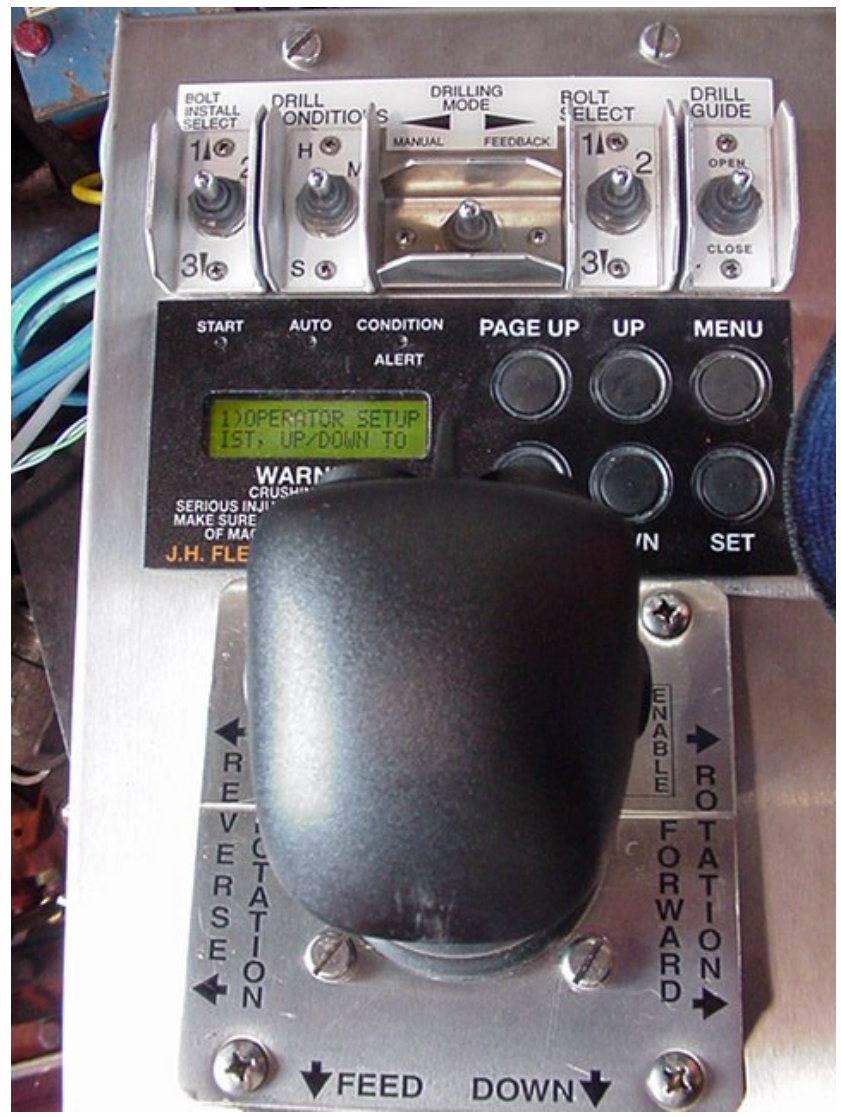

Fig. 1 Drilling Feedback Control System Developed by the J.H. Fletcher \& Company 


\section{A. Development of Operator Control Technology for Monitoring Roof Bolter Drill Operation Parameters.}

J. H. Fletcher is retrofitting a dual-boom roofbolter with the feedback control system dedicated to this project. It will be ready for laboratory testing in early May 2001. Laboratory tests similar to those described in the paper by Finfinger et al., (2001) are scheduled for early May 2001 as soon as work on the dedicated roofbolter is completed.

A meeting between West Virginia University and J. H. Fletcher \& Company was held on April 10 in Huntington, WV to discus and finalize the modifications of the feedback control system and laboratory testing schedule.

\section{B. Drill Parameter Data Analysis and Correlation with Roof Stability Condi- tions}

The preliminary data were analyzed by using the Multivariate Discriminant Analysis. The results are promising with higher percentage of correlation of drilling parameters with rock types. The analysis continues.

\section{Software Development for Mapping of Roof Geological Conditions}

None during this period.

\section{Computer Modeling to Investigate the Mechanisms of Roof Bolting}

Computer modeling of roof bolting consists of two parts: tensioned and fullygrouted resin bolts. The finite element computer program "ABAQUS" is leased for this task. In order to be realistic considering the dynamic nature of mine structures, only 3-dimensional models with nonlinear plastic behavior and bedding plane effects will be used.

In the tensioned bolt modeling, four models have been completed. It found:

1. Due to element size and number, a two-step modeling is required. The global model is to reduce the boundary effect while the sub-models are used to zoom in certain local areas and be set up beyond the stress concentration zones.

2. In order to reduce element number, symmetrical models with half of the entry system must be used.

3. Sliding and separation can be obtained.

4. The influence zone of applied tension within the bolting horizons can be determined. The next step is to run more models using different rock layer sequences and rock properties.

In the modeling of the fully-grouted resin bolts, the bolts are simulated as beam elements tied to the resin elements. The interaction between rock layers and between resin and rock are considered. Modeling is underway to study the effects of 
various parameters on the performance of the fully grouted bolts including geology, bolt spacing, bolt length and resin type.

\section{CONCLUSIONS}

The project proceeds well in this quarter. Many of the proposed tasks have been under way.

\section{$\underline{\text { Reference }}$}

1. G. B. Finfinger, S. S. Peng, Y. Luo, and G. Wilson, "Roof Bolter Drilling Measurements for Identifying Geological Properties of Mine Roof Rocks," Paper presented at the 2001 SME Annual Meeting, Denver, CO, February 26-28, 2001. 